\title{
Pengaruh kesehatan dan keselamatan kerja (K3), dan insentif terhadap motivasi serta kinerja karyawan pada bagian produksi
}

\section{Effect of health and work safety, and incentive to motivation and employee's performance in production division}

\author{
Anthony Frans \\ Departemen Ilmu Administrasi Publik, Program Pasca Sarjana, Universitas Nusa Cendana \\ Jalan Adisucipto, Penfui-Kupang, NTT, Indonesia \\ E-mail: anthony.frans@yahoo.co.id
}

\begin{abstract}
The human factor is an important factor in implementing vision, mission in achieving company target. Human resources aspect need to get more attention from the company. Example of consideration that was given by the company is the provision of Occupational Health and Safety (K3) to the employees. This research examines a hypothesis, known as explanatory research. The research purpose are to explaining and analyzing the effect of work safety to work motivation; effect of work health to work motivation; understanding and analyzing the effect of incentive to employee performance; and explaining and analyzing the effect of motivation to employee performance in CV. Intan Mandiri Pratam, Kupang. In this research, work motivation was set as intervening variable. Direct impact between (K3) and incentive to employee are higher compare to K3 and incentive to motivation as variable. This research found that $K 3$ and incentive are more impactful to worker compare to motivation as variable.
\end{abstract}

Keywords: occupational safety, occupational health, incentive, motivation, employee performance

\begin{abstract}
Abstrak
Faktor manusia merupakan faktor penentu keberhasilan dalam menjalankan visi, misi, dan dalam mencapai target perusahaan, maka dari itu sumber daya manusia perlu mendapatkan perhatian lebih dari perusahaan. Perhatian lebih yang diberikan oleh perusahaan salah satunya adalah dengan pemberian Kesehatan dan Keselamatan Kerja (K3) kepada para karyawan. Penelitian yang digunakan menguji hipotesis adalah explanatory reasearch. Penelitian ini bertujuan untuk menjelaskan dan menganalisis pengaruh keselamatan kerja terhadap motivasi kerja, pengaruh kesehatan kerja terhadap motivasi kerja, mengetahui dan menjelaskan serta menganalisis pengaruh insentif terhadap motivasi kerja, pengaruh keselamatan kerja terhadap kinerja karyawan, pengaruh kesehatan kerja terhadap kinerja karyawan, pengaruh insentif terhadap kinerja karyawan, serta menjelaskan dan menganalisi pengaruh motivasi terhadap kinerja karyawan di CV. Intan Mandiri Pratama Kupang. Pengaruh secara langsung antara Kesehatan dan Keselamatan Kerja (K3) dan insentif terhadap variabel kinerja karyawan lebih tinggi bila dibandingkan dengan pengaruh tidak langsung antara variabel Kesehatan dan Keselamatan Kerja (K3) dan insetif terhadap variabel motivasi. Hasil dari penelitian ini adalah Kesehatan dan Keselamatan Kerja (K3) dan insentif lebih besar pengaruhnya tanpa harus melalui motivasi kerja.
\end{abstract}

Kata kunci: keselamatan kerja, kesehatan kerja, insentif, motivasi, kinerja karyawan

\section{Pendahuluan}

Saat ini banyak berbagai sumber berita elektronik dan artikel di koran yang gencar membahas masalah pengembangan Kesehatan dan Keselamatan Kerja (K3), berbagai perusahaan menerapkan Kesehatan dan Keselamatan Kerja (K3) guna menciptakan lingkungan yang kondusif, dan bertujuan untuk mendukung proses peningkatan kinerja karyawan. Sumber daya manusia mempunyai peranan penting dalam suatu organisasi sebagai ujung tombak kehidupan suatu organisasi itu sendiri. Menyadari bahwa manusia adalah sangat penting dan menjadi pusat perhatian setiap kegiatan, maka perusahaan dituntut untuk mengelola sumber daya manusia yang ada dengan baik. Hal ini agar tujuan yang diharapkan dapat tercapai, dengan berorientasi pada penggunaan sumber daya yang efektif dan efisien. 
Faktor manusia merupakan faktor penentu keberhasilan dalam menjalankan visi, misi, dan dalam mencapai target perusahaan, maka dari itu sumber daya manusia perlu mendapatkan perhatian lebih dari perusahaan. Perhatian lebih yang diberikan oleh perusahaan salah satunya adalah dengan pemberian Kesehatan dan Keselamatan Kerja (K3) kepada para karyawan. Menurut Notoatmodjo (2009:153) tujuan utama Kesehatan dan Keselamatan Kerja (K3) adalah agar karyawan atau pegawai di sebuah institusi mendapat kesehatan yang optimal, sehingga mencapai produktivitas kerja yang setinggi-tingginya. Menurut Mangkunegara (2004:162), selain bertujuan untuk menghindari kecelakaan dalam proses produksi perusahaan, Kesehatan dan Keselamatan Kerja (K3) juga bertujuan untuk meningkatkan kegairahan, keserasaian kerja, dan partisipasi kerja karyawan dan dapat dipastikan kinerja dari karyawan meningkat. Ketika karyawan merasa terjamin keselamatan dan kesehatan kerja, serta disertai dengan pemberian insentif maka ekspektasi terhadap karyawan agar bekerja optimal dengan sangat tinggi, sedangkan insentif seringkali diartikan sebagai penggerak atau pendorong yang diberikan dengan sengaja kepada para pekerja, agar dalam diri mereka timbul semangat yang lebih besar untuk berprestasi. Insentif sebagai perangsang agar supaya para karyawan bekerja dengan penuh tanggung jawab, sehingga kinerja karyawan dapat tercapai.

Motivasi merupakan faktor psikologis yang menunjukan minat individu terhadap pekerjaan, rasa puas dan ikut bertanggung jawab terhadap aktivitas atau pekerjaan yang dilakukan. Perilaku seseorang pada umumnya dimotivasi oleh keinginan untuk memperoleh tujuan tertentu. Motivasi merupakan hal yang penting untuk diperhatikan, karena dengan motivasi seorang karyawan atau pegawai akan dapat memiliki semangat yang tinggi dalam melaksakan tugas. CV. Intan Mandiri Pratama merupakan perusahaan swasta yang berbentuk badan hukum dan berkedudukan di Kupang. Dalam kegiatan produksinya CV. Intan Mandiri Pratama merupakan perusahaan yang bergerak dalam bidang pembuatan genteng beton. CV. Intan Mandiri Pratama memiliki kantor yang berada di Jl. Jend. Soeharto No. 128, Kupang. CV. Intan Mandiri Pratama merupakan salah satu perusahaan yang menerapkan Keselamatan dan Kesehatan Kerja (K3). Keselamatan dan Kesehatan Kerja (K3) diterapkan di bagian produksi yang terdiri dari tiga sub bagian, yaitu bagian material dan processing, bagian assembling, dan bagian quality control. Karyawan bagian produksi harus mengutamakan keselamatan kerja karena kegiatan produksinya yang beresiko tinggi.

K3 sangat penting bagi semua orang di manapun berada terlebih di lingkungan kerja. Era globalisasi ini membuat semua perusahaan harus berupaya untuk meningkatkan K3, selain itu juga harus menjadi prioritas dan komitmen semua pihak baik pemerintah maupun swasta dari tingkat pimpinan sampai ke seluruh karyawan dalam manajemen perusahaan. Dengan tingkat kesehatan dan keselamatan kerja yang baik jelas mangkir kerja karena sakit akan menurun, biaya pengobatan dan perawatan akan menurun, kerugian akibat kecelakaan akan berkurang, tenaga kerja akan mampu bekerja dengan lebih tinggi, keuntungan akan meningkat dan tentunya kesejahteraan karyawan akan meningkat. Berdasarkan uraian tersebut, penulis tertarik untuk melakukan penelitian di mana sebuah perusahaan yang bisa memberikan jaminan Kesehatan dan Keselamatan Kerja (K3) dan memberikan insentif, sehingga memotivasi karyawan untuk meningkatkan kinerjanya.

\section{Metode Penelitian}

Penelitian ini dilaksanakan untuk mengetahui pengaruh dari keselamatan, kesehatan kerja dan insentif terhadap motivasi dan kinerja karyawan. Untuk mengetahui pengaruh hal tersebut, peneliti akan melakukan pengujian hipotesis. Penelitian yang digunakan menguji hipotesis adalah explanatory reasearch. Menurut Singarimbun (2006:5), "explanatory research atau penelitian penjelasan adalah penelitian yang menjelaskan hubungan kausal antara variabel-variabel melalui pengujian hipotesa". Jadi, hubungan kausal antara variabel-variabel yang ada dibuktikan melalui pengujian hipotesis. Dalam penelitian expalantory research, hipotesis yang telah dirumuskan akan diuji untuk mengetahui adanya hubungan dan pengaruh antara variabel yang hendak diteliti. Variabel-variabel yang hendak diteliti dalam penelitian ini, yaitu keselamatan, kesehatan kerja, dan insentif terhadap motivasi dan kinerja karyawan. Penelitian ini akan menggunakan kuesioner sebagai alat pengumpulan data yang utama, sehingga dengan demikian jenis penelitian ini adalah penelitian survei. 


\section{Analisis deskriptif}

Analisis ini digunakan untuk mendeskripsikan penelitian responden dan distribusi item masingmasing variabel. Data yang dikumpulkan diedit dan ditabulasikan dalam tabel, kemudian dibahas secara deskriptif. Ukuran deskriptifnya adalah pemberian angka, baik dalam jumlah responden maupun dalam angka prosentase.

\section{Analisis inferensial}

Analisis statistik inferensial dapat dikatakan sebagai metode analisis dengan menggunakan data yang berbentuk angka dan di analisis dengan cara membandingkan melalui perhitungan dan mengaplikasikannya dengan cara menggunakan rumus yang sesuai. Analisis statistik inferensial digunakan untuk menguji parameter populasi data yang ada, dengan menggunakan data yang berasal dari responden. Dalam penelitian ini dianalisis dengan program SPSS 17.0 for Windows, hal ini mempermudah mengelola data yang berbentuk angka statistik dan kemudian dapat diambil simpulannya. Analisis statistik inferensial yang digunakan dalam penelitian ini adalah analisis jalur atau path analysis dan uji hipotesis (uji t).

\section{Analisis jalur/path analisis}

Penelitian ini dalam rangka menguji hipotesis, dibuktikan dengan pendekatan analisis jalur (Path Analysis). Riduwan dan Kuncoro (2008:116) berpendapat bahwa pada dasarnya koefisien jalur (path) adalah koefisien regresi yang distandarkan, yaitu koefisien regresi yang dihitung dari basis data yang telah diset dalam angka baku atau Z-score (data yang diset dengan nilai rata-rata $=0$ dan standar deviasi = 1). Koefisien jalur yang distandarkan (standardized path coefficient) ini digunakan untuk menjelaskan besarnya pengaruh (bukan memprediksi) variabel bebas (eksogen) terhadap variabel lain yang diberlakukan sebagai variabel terikat (endogen)".

\section{Uji hipotesis (Uji t)}

Pengujian hipotesis bertujuan untuk menguji apakah hipotesis yang telah dilakukan pada penelitian diterima atau tidak. Hipotesis penelitian yang akan diuji dirumuskan menjadi hipotesis statistik berikut (Riduwan dan Kuncoro 2008:117-118):

$$
\text { Ha: } \text { pyx }_{1}>0
$$

$\mathrm{H}_{0}: \operatorname{pyx}_{1}<0$

Rumus uji t yang dihitung dengan rumus (Schumacker dan Lomax, dalam Riduwan dan Kuncoro 2008:117-118):

$$
\mathrm{t}_{k}=\frac{P k}{s e_{p k}}
$$

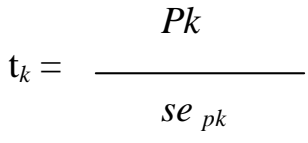

Keterangan:

Statistik se $\mathrm{px}_{1}$ diperoleh dari hasil komputasi pada SPSS untuk analisis regresi setelah data ordinal ditransformasikan ke interval. Selanjutnya untuk mengetahui signifikasi analisis jalur bandingkan antara nilai probabilitas 0,05 dengan nilai probabilitas Sig dengan dasar pengambilan keputusan sebagai berikut: 1) Jika nilai probabilitas 0,05 lebih kecil atau sama dengan dengan nilai probabilitas Sig atau $(0,05 \leq \mathrm{Sig})$, maka $\mathrm{H}_{0}$ diterima dan $\mathrm{H}_{\mathrm{a}}$ ditolak artinya tidak signifikan, 2) Jika nilai probabilitas 0,05 lebih besar atau sama dengan dengan nilai probabilitas Sig atau $(0,05 \geq$ Sig), maka $\mathrm{H}_{0}$ ditolak dan $\mathrm{H}_{\mathrm{a}}$ diterima artinya signifikan. 


\section{Hasil Penelitian dan Pembahasan}

Hasil analisis jalur

Analisis jalur model pertama $\left(X_{1}, X_{2}, X_{3}\right.$ terhadap $\left.Z\right)$

Tabel 1.

Hasil analisis jalur model pertama $\left(\mathrm{X}_{1}, \mathrm{X}_{2}, \mathrm{X}_{3}\right.$ terhadap Z)

\begin{tabular}{lllll}
\hline \multicolumn{5}{l}{ Standarized } \\
Variabel bebas & koefisien beta & t hitung & Probabilitas & Keterangan \\
\hline $\mathrm{X} 1$ & 0.361 & 3.508 & 0.001 & Signifikan \\
$\mathrm{X} 2$ & 0.363 & 3.611 & 0.001 & Signifikan \\
$\mathrm{X} 3$ & 0.224 & 2.461 & 0.017 & Signifikan \\
Variabel terikat & $\mathrm{Z}$ & & & \\
$\mathrm{R}$ & $: 0,754$ & & & \\
R square (R2) & $: 0,569$ & & & \\
Adjusted R square & $: 0,548$ & & & \\
F hitung & $: 27,294$ & & & \\
Probabilitas Fhitung & $: 0,000$ & & & \\
\hline
\end{tabular}

Sumber: Data primer diolah 2015

Berdasarkan Tabel 1. dapat diketahui pengaruh yang signifikan antara variabel keselamatan kerja karyawan, kesehatan kerja karyawan, dan pemberian insentif terhadap motivasi kerja. Dari hasil uji koefisien path pada Tabel 1. didapatkan nilai probabilitas Fhitung sebesar 0,000 ( $\mathrm{p}<0,05)$, sehingga H0 ditolak, karena H0 ditolak maka hipotesis yang menyatakan bahwa terdapat pengaruh yang signifikan secara bersama-sama (simultan) antara keselamatan kerja karyawan, kesehatan kerja karyawan, dan pemberian insentif terhadap motivasi kerja dapat diterima. Besarnya sumbangan (kontribusi) variabel keselamatan kerja karyawan, kesehatan kerja karyawan, dan pemberian insentif terhadap motivasi kerja dapat dilihat dari nilai Adjusted $R$ Square, yaitu sebesar 0,548. Artinya bahwa $54,8 \%$ variabel motivasi kerja akan dipengaruhi oleh variabel bebasnya, yaitu keselamatan kerja karyawan, kesehatan kerja karyawan, dan pemberian insentif, sedangkan sisanya 45,2\% variabel motivasi kerja akan dipengaruhi oleh variabel-variabel yang lain yang tidak dibahas dalam penelitian ini.

Pengaruh variabel keselamatan kerja karyawan (X1) terhadap motivasi kerja (Z). Dari hasil perhitungan secara parsial variabel keselamatan kerja karyawan (X1) mempunyai pengaruh langsung yang positif dan signifikan terhadap motivasi kerja $(Z)$ pada tingkat kesalahan $0,05(\alpha=5 \%)$ apabila variabel lain diasumsikan konstan. Hal ini dapat dibuktikan dengan besarnya koefisien path sebesar 0,361 dengan nilai probabilitas $\mathrm{t}$ sebesar $0,001(0,001<0,05)$ maka secara parsial variabel keselamatan kerja karyawan (X1) berpengaruh signifikan terhadap motivasi kerja (Z).

Pengaruh variabel kesehatan kerja karyawan (X2) terhadap motivasi kerja (Z). Dari hasil perhitungan secara parsial variabel kesehatan kerja karyawan (X2) mempunyai pengaruh langsung yang positif dan signifikan terhadap motivasi kerja $(Z)$ pada tingkat kesalahan $0,05(\alpha=5 \%)$ apabila variabel lain diasumsikan konstan. Hal ini dapat dibuktikan dengan besarnya koefisien path sebesar 0,363 dengan nilai probabilitas t sebesar $0,001(0,001<0,05)$ maka secara parsial variabel kesehatan kerja karyawan (X2) berpengaruh signifikan terhadap motivasi kerja (Z).

Pengaruh variabel pemberian insentif (X3) terhadap motivasi kerja (Z). Dari hasil perhitungan secara parsial variabel pemberian insentif (X3) mempunyai pengaruh langsung yang positif dan signifikan terhadap motivasi kerja $(\mathrm{Z})$ pada tingkat kesalahan $0,05(\alpha=5 \%)$ apabila variabel lain diasumsikan konstan. Hal ini dapat dibuktikan dengan besarnya koefisien path sebesar 0,224 dengan nilai probabilitas t sebesar $0,017(0,017<0,05)$ maka secara parsial variabel pemberian insentif $(\mathrm{X} 3)$ 
berpengaruh signifikan terhadap motivasi kerja (Z).

Analisis jalur model kedua $\left(X_{1}, X_{2}, X_{3}, Z\right.$ terhadap $\left.Y\right)$

Tabel 2.

Hasil analisis jalur model kedua $\left(\mathrm{X}_{1}, \mathrm{X}_{2}, \mathrm{X}_{3}\right.$, Zterhadap $\left.\mathrm{Y}\right)$

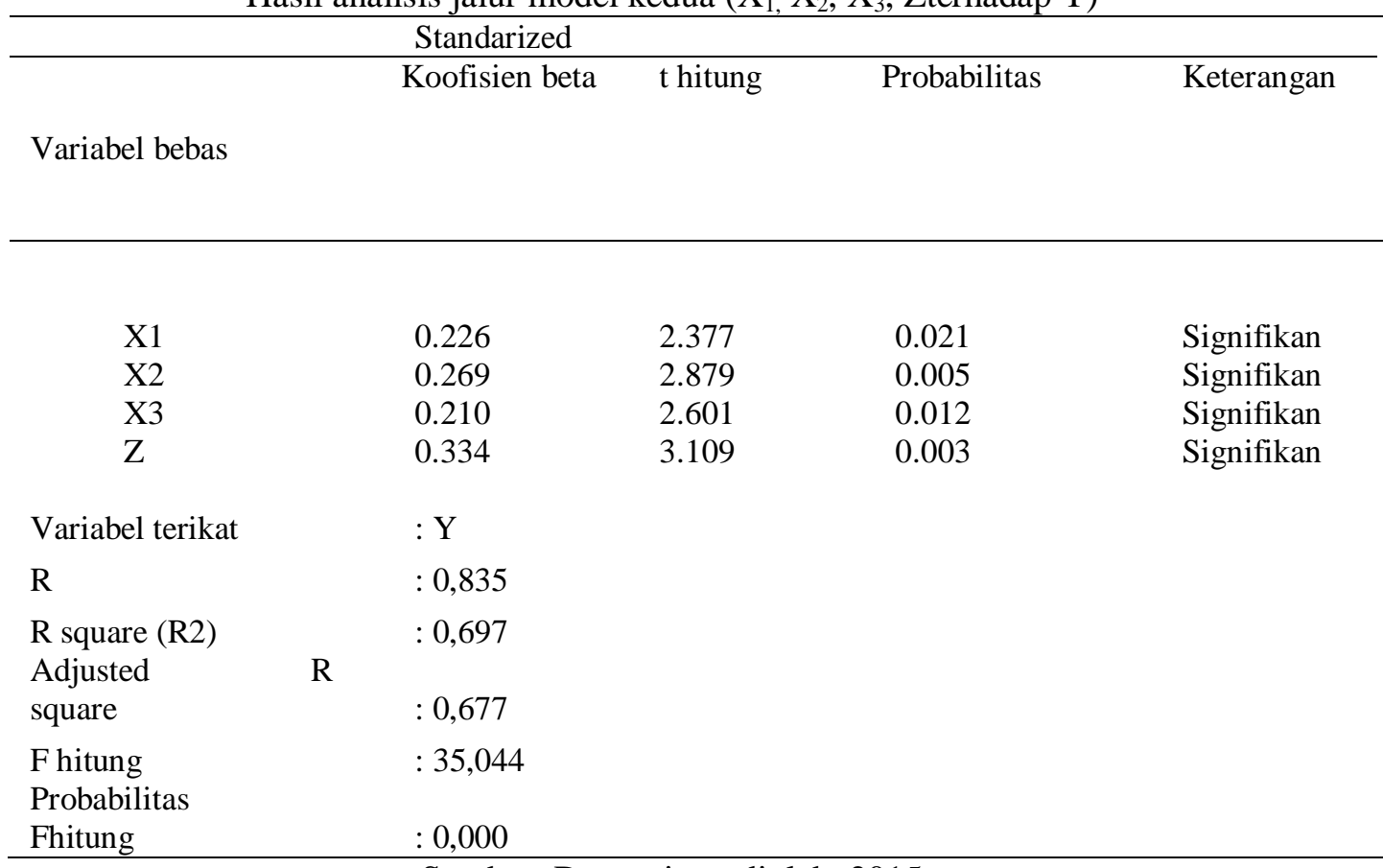

Sumber: Data primer diolah, 2015

Berdasarkan Tabel 2. dapat diketahui pengaruh yang signifikan antara variabel keselamatan kerja karyawan, kesehatan kerja karyawan, pemberian insentif, dan motivasi kerja terhadap kinerja karyawan. Dari hasil uji koefisien path pada Tabel 2. didapatkan nilai probabilitas F hitung sebesar 0,000 ( $\mathrm{p}<0,05$ ), sehingga H0 ditolak, karena H0 ditolak maka hipotesis yang menyatakan bahwa terdapat pengaruh yang signifikan secara bersama-sama (simultan) antara kesehatan kerja karyawan, pemberian insentif, dan motivasi kerja terhadap kinerja karyawan dapat diterima. Besarnya sumbangan (kontribusi) variabel keselamatan kerja karyawan, kesehatan kerja karyawan, dan pemberian insentif terhadap motivasi kerja dapat dilihat dari nilai Adjusted $R$ Square,yaitu sebesar 0,677. Artinya bahwa 67,7\% variabel kinerja karyawan akan dipengaruhi oleh variabel bebasnya, yaitu keselamatan kerja karyawan, kesehatan kerja karyawan, pemberian insentif, dan motivasi kerja, sedangkan sisanya 32,3\% variabel kinerja karyawan akan dipengaruhi oleh variabel variabel yang lain yang tidak dibahas dalam penelitian ini.

\section{Pengaruh keselamatan kerja dan kesehatan kerja karyawan serta pemberian insentif terhadap motivasi kerja}

Berdasarkan analisis statistik inferensial dengan menggunakan analisis jalur (path analysis), maka hipotesis pertama yang menyatakan terdapat pengaruh antara keselamatan kerja karyawan terhadap motivasi kerja sudah terbukti dan hipotesis tersebut terbukti dan dapat diterima. Pengaruh tersebut signifikan, sehingga semakin dilaksanakan dengan baik keselamatan kerja karyawan yang diberikan oleh CV. Intan Mandiri Pratama kepada karyawan akan dapat memotivasi karyawan untuk bekerja dengan lebih baik lagi. Selanjutnya hasil ini juga diperkuat oleh pendapat Mangkunegara (2004:162), "selain bertujuan untuk menghindari kecelakaan kerja dalam proses produksi perusahaan, program keselamatan dan kesehatan kerja juga untuk meningkatkan kegairahan, keserasian kerja dan partisipasi kerja karyawan", maka bisa dipastikan motivasi dari karyawan akan meningkat. Hipotesis kedua menyatakan bahwa terdapat pengaruh antara kesehatan kerja karyawan terhadap motivasi kerja. 
Hipotesis tersebut terbukti dan dapat diterima, hubungan tersebut bersifat signifikan, sehingga dapat dikatakan bahwa kesehatan kerja karyawan yang diberikan CV. Intan Mandiri Pratama juga dapat memotivasi karyawan untuk lebih bekerja dengan giat dan meningkatkan kualitas dari pekerjaannya. Hipotesis ketiga menyatakan bahwa terdapat pengaruh antara pemberian insentif terhadap motivasi kerja. Hipotesis tersebut terbukti dan dapat diterima, hubungan tersebut bersifat signifikan, sehingga dapat dikatakan bahwa insentif yang diberikan CV. Intan Mandiri Pratama juga dapat memotivasi karyawan untuk lebih bekerja dengan giat dan meningkatkan kualitas dari pekerjaannya. Hal ini juga didukung oleh pernyataan Notoatmodjo (2009:153), yang menyatakan bahwa, "Besar kecilnya kompensasi dapat mempengaruhi prestasi kerja, motivasi dan kepuasan kerja karyawan. Apabila kompensasi diberikan secara tepat dan benar para karyawan akan memperoleh kepuasan dalam bekerja dan termotivasi untuk mencapai tujuan-tujuan organisasi. Akan tetapi bila kompensasi yang diberikan tidak memadai atau kurang tepat, prestasi kerja, motivasi, dan kepuasan kerja karyawan akan menurun".

Kesimpulan yang diperoleh adalah bahwa keselamatan kerja karyawan dan kesehatan kerja karyawan serta pemberian insentif berpengaruh signifikan terhadap motivasi kerja. Pengaruh variabel keselamatan kerja karyawan $\left(X_{1}\right)$ dan variabel kesehatan kerja karyawan $\left(X_{2}\right)$ serta pemberian insentif (X3) adalah sebagai berikut: a) Variabel keselamatan kerja karyawan $\left(\mathrm{X}_{1}\right)$ merupakan variabel yang berpengaruh secara signifikan terhadap motivasi kerja $(Z)$ hal ini ditunjukkan dengan signifikan $t$ sebesar 0,001 yang lebih kecil dari 0,05. Hal ini menunjukkan bahwa keselamatan kerja karyawan $\left(\mathrm{X}_{1}\right)$ mempunyai pengaruh yang signifikan terhadap variabel motivasi kerja $(\mathrm{Z})$, b) Variabel kesehatan kerja karyawan $\left(\mathrm{X}_{2}\right)$ merupakan variabel yang berpengaruh secara signifikan terhadap motivasi kerja $(Z)$ hal ini ditunjukkan dengan signifikan t sebesar 0,001 yang lebih kecil dari 0,05. Hal ini menunjukkan bahwa kesehatan kerja karyawan $\left(X_{2}\right)$ mempunyai pengaruh yang signifikan terhadap variabel motivasi kerja $(\mathrm{Z})$, c) Variabel pemberian insentif $\left(\mathrm{X}_{3}\right)$ merupakan variabel yang berpengaruh secara signifikan terhadap motivasi kerja $(Z)$ hal ini ditunjukkan dengan signifikan $t$ sebesar 0,017 yang lebih kecil dari 0,05. Hal ini menunjukkan bahwa pemberian insentif $\left(\mathrm{X}_{3}\right)$ mempunyai pengaruh yang signifikan terhadap variabel motivasi kerja $(\mathrm{Z})$.

\section{Pengaruh keselamatan kerja karyawan dan kesehatan kerja karyawan serta pemberian insentif terhadap kinerja karyawan}

Berdasarkan analisis statistik inferensial dengan menggunakan analisis jalur (path analysis), maka hipotesis keempat yang menyatakan terdapat pengaruh antara keselamatan kerja karyawan terhadap kinerja karyawan sudah terbukti dan hipotesis tersebut terbukti dan dapat diterima. Pengaruh tersebut signifikan, sehingga pelaksanaan dari keselamatan kerja karyawan yang diberikan oleh CV. Intan Mandiri Pratama kepada karyawan akan dapat menambah kinerja dari karyawan itu sendiri di dalam penyelesaian pekerjaannya. Hasil penelitian ini juga diperkuat oleh pendapat Mangkunegara (2004:162), "selain bertujuan untuk menghindari kecelakaan kerja dalam proses produksi perusahaan, program keselamatan dan kesehatan kerja juga untuk meningkatkan kegairahan, keserasian kerja dan partisipasi kerja karyawan", dengan meningkatnya kegairahan, keserasian kerja dan partisipasi kerja karyawan maka akan berdampak pada meningkatnya kinerja karyawan. Hipotesis kelima menyatakan bahwa terdapat pengaruh antara kesehatan kerja karyawan terhadap kinerja karyawan. Hipotesis tersebut terbukti dan dapat diterima, hubungan tersebut bersifat signifikan, sehingga dapat dikatakan bahwa dengan pemberian kesehatan kerja karyawan pada karyawan CV. Intan Mandiri Pratama memacu karyawan agar lebih meningkatkan kinerjanya untuk bekerja dengan baik. Hipotesis keenam menyatakan bahwa terdapat pengaruh antara pemberian insentif terhadap kinerja karyawan. Hipotesis tersebut terbukti dan dapat diterima, hubungan tersebut bersifat signifikan, sehingga dapat dikatakan bahwa dengan pemberian insentif yang baik kepada karyawan CV. Intan Mandiri Pratama memacu karyawan agar lebih meningkatkan kinerjanya untuk bekerja dengan baik. Sebagaimana yang dikemukakan oleh Mangkunegara (2004:84), "Kompensasi yang diberikan kepada karyawan sangat berpengaruh terhadap kepuasan dan motivasi kerja, di mana motivasi kerja dan kemampuan kerja nantinya akan mempengaruhi hasil kerja”.

Simpulan yang diperoleh adalah bahwa keselamatan kerja karyawan dan kesehatan kerja karyawan 
berpengaruh signifikan terhadap kinerja karyawan. Pengaruh variabel keselamatan kerja karyawan $\left(\mathrm{X}_{1}\right)$ dan variabel kesehatan kerja karyawan $\left(\mathrm{X}_{2}\right)$, serta pemberian insentif $\left(\mathrm{X}_{3}\right)$ adalah sebagai berikut: a) Variabel keselamatan kerja karyawan $\left(X_{1}\right)$ merupakan variabel yang berpengaruh secara signifikan terhadap kinerja karyawan (Y) hal ini ditunjukkan dengan signifikan t sebesar 0,021 yang lebih kecil dari 0,05. Hal ini menunjukkan bahwa keselamatan kerja karyawan $\left(X_{1}\right)$ mempunyai pengaruh yang signifikan terhadap variabel kinerja karyawan $(\mathrm{Y})$, b) Variabel kesehatan kerja karyawan $\left(\mathrm{X}_{2}\right)$ merupakan variabel yang berpengaruh secara signifikan terhadap kinerja karyawan (Y) hal ini ditunjukkan dengan signifikan t sebesar 0,005 yang lebih kecil dari 0,05. Hal ini menunjukkan bahwa kesehatan kerja karyawan $\left(\mathrm{X}_{2}\right)$ mempunyai pengaruh yang signifikan terhadap variabel kinerja karyawan $(\mathrm{Y})$, c) Variabel pemberian insentif $\left(\mathrm{X}_{3}\right)$ merupakan variabel yang berpengaruh secara signifikan terhadap kinerja karyawan $(\mathrm{Y})$ hal ini ditunjukkan dengan signifikan $\mathrm{t}$ sebesar 0,012 yang lebih kecil dari 0,05 . Hal ini menunjukkan bahwa pemberian insentif $\left(X_{3}\right)$ mempunyai pengaruh yang signifikan terhadap variabel kinerja karyawan (Y).

\section{Pengaruh motivasi kerja terhadap kinerja karyawan}

Berdasarkan analisis statistik inferensial dengan menggunakan analisis jalur (path analysis), maka hipotesis ketujuh yang menyatakan terdapat pengaruh antara motivasi kerja terhadap kinerja karyawan sudah terbukti dan hipotesis tersebut terbukti dan dapat diterima. Pengaruh tersebut signifikan, sehingga semakin kuat motivasi kerja maka semakin tinggi kinerja dari karyawan CV. Intan Mandiri Pratama. Simpulan yang diperoleh adalah bahwa motivasi kerja berpengaruh signifikan terhadap kinerja karyawan. Pengaruh variabel motivasi kerja (Z) secara parsial, adalah sebagai berikut: Variabel motivasi kerja (Z) merupakan variabel yang berpengaruh secara signifikan terhadap kinerja karyawan $(\mathrm{Y})$ hal ini ditunjukkan dengan signifikan $\mathrm{t}$ sebesar 0,003 yang lebih kecil dari 0,05. Hal ini menunjukkan bahwa motivasi kerja $(Z)$ mempunyai pengaruh yang signifikan terhadap variabel kinerja karyawan (Y). Variabel kinerja karyawan memiliki rata-rata kurang dari 4, meskipun rata-rata kinerja kurang dari 4 masih termasuk dalam kategori yang baik karena masih berada dalam selang 3,5-4,2. Hal tersebut dikarenakan adanya beberapa karyawan yang memiliki K3 yang baik namun masih ada yang melakukan tindakan ketidakdisiplinan dalam melakukan kerja, seperti saling bercanda saat bekerja yang dapat menyebabkan kelalaian dalam bekerja, hal tersebut yang harus mendapatkan perhatian lebih agar karyawan dapat lebih disiplin lagi dalam bekerja.

\section{Simpulan}

Berdasarkan permasalahan yang telah dirumuskan, hasil analisis dan pengujian hipotesis yang telah dilakukan pada pembahasan sebelumnya, maka dari penelitian yang dilakukan dapat diambil simpulan sebagai berikut: 1) Keselamatan dan Kesehatan Kerja (K3), insentif, motivasi kerja dan kinerja karyawan memiliki kategori penilaian yang baik karena semua memiliki rata-rata di antara 3,5 $-4,2,2)$ hasil penelitian menunjukkan bahwa variabel keselamatan kerja karyawan berpengaruh positif dan signifikan terhadap motivasi kerja $(Z)$ ini dibuktikan dengan nilai probabilitas < 0,05 yang berarti ada pengaruh yang signifikan, 3) hasil penelitian menunjukkan bahwa variabel kesehatan karyawan berpengaruh positif dan signifikan terhadap motivasi kerja $(Z)$ ini dibuktikan dengan nilai probabilitas $<0,05$ yang berarti ada pengaruh yang signifikan, 4) hasil penelitian menunjukkan bahwa variabel pemberian insentif berpengaruh positif dan signifikan terhadap motivasi kerja $(Z)$ ini dibuktikan dengan nilai probabilitas $<0,05$ yang berarti ada pengaruh yang signifikan, 5) hasil penelitian menunjukkan bahwa variabel keselamatan kerja karyawan berpengaruh positif dan signifikan terhadap kinerja karyawan (Y) ini dibuktikan dengan nilai probabilitas < 0,05 yang berarti ada pengaruh yang signifikan, 6) hasil penelitian menunjukkan bahwa variabel kesehatan karyawan berpengaruh positif dan signifikan terhadap kinerja karyawan (Y) ini dibuktikan dengan nilai probabilitas $<0,05$ yang berarti ada pengaruh yang signifikan, 7) hasil penelitian menunjukkan bahwa variabel pemberian insentif berpengaruh positif dan signifikan terhadap kinerja karyawan (Y) ini dibuktikan dengan nilai probabilitas $<0,05$ yang berarti ada pengaruh yang signifikan, 8) hasil penelitian menunjukkan bahwa variabel motivasi kerja berpengaruh positif dan signifikan terhadap kinerja karyawan (Y) ini dibuktikan dengan nilai probabilitas < 0,05 yang berarti ada pengaruh yang 
Frans: "Pengaruh kesehatan dan keselamatan kerja (K3), dan insentif terhadap motivasi serta kinerja karyawan..."

signifikan.

\section{Daftar Pustaka}

Notoatmodjo S (2009) Pengembangan sumber daya manusia, edisi revisi. Jakarta: Rineka Cipta.

Mangkunegara AAAP (2004) Manajemen sumber daya manusia perusahaan. Bandung: Remaja

Rosda Karya.

Sadeli dan Bayu Prawira Hie. Jakarta: Salemba Empat.

Singarimbun M (2006) Metode penelitian survei. Jakarta: LP3ES.

Riduwan \& Kuncoro EA (2008) Cara menggunakan dan memakai path analysis (analisis jalur).

Bandung: Alfabeta. 